Please do not remove this page

RMIT

UNIVERSITY

\title{
Apologies for forced adoption practices: Implications for contemporary intercountry adoption
}

Fronek, Patricia; Cuthbert, Denise

https://researchrepository.rmit.edu.au/esploro/outputs/9921861941801341/filesAndLinks?institution=61RMIT_INST\&index=null

Fronek, P., \& Cuthbert, D. (2013). Apologies for forced adoption practices: Implications for contemporary intercountry adoption. Australian Social Work, 66, 402-414.

https://doi.org/10.1080/0312407X.2013.777970

Document Version: Submitted Version

Published Version: https://doi.org/10.1080/0312407X.2013.777970

Repository homepage: https://researchrepository.rmit.edu.au (c) 2013 Copyright Australian Association of Social Workers.

Downloaded On 2023/04/26 19:49:01 +1000 
Thank you for downloading this document from the RMIT Research Repository.

The RMIT Research Repository is an open access database showcasing the research outputs of RMIT University researchers.

RMIT Research Repository: http://researchbank.rmit.edu.au/

\section{Citation:}

Fronek, P and Cuthbert, D 2013, 'Apologies for forced adoption practices: Implications for contemporary intercountry adoption', Australian Social Work, vol. 66, no. 3, pp. 402-414.

See this record in the RMIT Research Repository at:

https://researchbank.rmit.edu.au/view/rmit:21956

Version: Submitted Version

Copyright Statement: ㄷ 2013 Copyright Australian Association of Social Workers

Link to Published Version:

http://dx.doi.org/10.1080/0312407X.2013.777970 


\section{Apologies for forced adoption practices: Implications for contemporary intercountry adoption}

Patricia Fronek $^{\mathrm{a}}$ and Denise Cuthbert ${ }^{\mathrm{b}}$

${ }^{a}$ School of Human Services and Social Work; Griffith Health Institute, Population and Social Health Research Program; Griffith University, Australia.

b School of Graduate Research, RMIT University

Correspondence should be addressed to:

Patricia Fronek

School of Human Services and Social Work, Gold Coast Campus, Griffith University, QLD 4222, Australia

Email: p.fronek@griffith.edu.au 
Running Head: APOLOGIES FOR FORCED ADOPTION PRACTICES

\title{
Apologies for forced adoption practices: Implications for contemporary intercountry adoption
}

\begin{abstract}
2012 marks historic events in the practice of adoption in Australia. Government focus is on the formulation of apologies to those people affected by past forced adoption practices. A critical reflection on these and other Australian apologies, highlight assumptions that differentiate past domestic adoption practices from past and contemporary practice in intercountry adoption. The importance of social work, founded in the values of social justice and human rights, to ensuring the same practice standards apply to all people who give birth to children regardless of where they live is highlighted. Expanding knowledge on intercountry adoption indicates that Australia should prepare for another apology.
\end{abstract}

\section{Keywords:}

\section{Apology, forced adoptions, Intercountry adoption}




\section{Running Head: APOLOGIES FOR FORCED ADOPTION PRACTICES}

\section{Introduction}

At the time of writing this paper in 2012, Australian states and territories are, oneby-one, formally apologizing to mothers, fathers and families affected by past forced adoptions within Australia. The federal Attorney-General's Department, watched closely by governments and communities affected by adoption in the Americas, Asia, Africa and Europe, is currently preparing for a national apology anticipated in March 2013 (Cuthbert \& Quartly, 2012; Fronek \& Cuthbert, 2012a). In August 2012, Australian adoption researchers wrote to the Chair of the Reference Group for the drafting of the commonwealth apology, Professor Nahum Mushin, proposing that the national apology for forced adoption practices be explicitly extended to those affected by forced adoption practices in intercountry adoption (Personal communication, August 21, 2012). The growing body of research on intercountry adoption prompted the authors to alert the Australian government of the need to frame its apology to all those people harmed by forced adoption practices to include intercountry adoption, in particular, overseas mothers who have no ready access to the Australian government to press their claims for themselves.

\section{Australia, child removal and apologies}

Australia leads the world in offering formal apologies to those people who as children were forcibly separated from their families through past government policies and social welfare practices. In 2008, Prime Minister Kevin Rudd apologized on behalf of Australia to the Stolen Generations, Indigenous people who as children endured forced separation from their families and communities and to the families who lost their children 


\section{Running Head: APOLOGIES FOR FORCED ADOPTION PRACTICES}

(Fejo-King, 2011). In 2009, the Forgotten Australians and Lost Innocents, former forced imperial child migrants and institutionalised children received an apology from the Prime Minister for the sufferings, abuse and lifelong harm many have suffered as a result of past policies which removed them from their families, their birth countries and communities (Cuthbert \& Quartly, 2012). These confirmatory acts and recognition of past abuses have been deemed essential for processes of reconciliation and healing for persons affected.

Australia’s apologies to the Stolen Generations, the Forgotten Australians and Lost Innocents have inspired activism by adults affected by adoption within Australia and adults in many countries who were adopted internationally as children (Cuthbert \& Quartly, 2012; Edwards, 2010; Fejo-King, 2011; Fronek, 2012). At the same time, these apologies have been criticized for failing to move beyond rhetoric by translating regret into tangible and appropriate action for those affected people (Short, 2012). As noted by Cuthbert and Quartly (2012), there is a strong tendency in Australian apologies delivered to date to draw clear lines between the past practices for which apologies are made and present practices, as if an apology is sufficient to mark a 'new chapter' in history and practice with respect to child removal. In the current debate on an apology for the harm caused by forced adoptions, the 'pastness' of practices that necessitate regret is highlighted in the terms of reference and the title of the Australian Senate's 2011 inquiry into 'past forced adoption practices.'

\section{Putting the past behind us...}

The salience of the idea of the past plays out in a particular way with respect to adoption and intercountry adoption specifically. Despite public and government 


\section{Running Head: APOLOGIES FOR FORCED ADOPTION PRACTICES}

acknowledgment of what constitutes unacceptable practices, past events remain disconnected from present practices in public consciousness and the realities of certain aspects of adoption. When reference is made to now unacceptable practices in past domestic adoptions and their negative impact on adoptees and their families, this past is emphatically quarantined from the 'present' (and the future) of intercountry adoption. This quarantining is articulated in evidence provided to the federal inquiry into Overseas Adoption in Australia, 2005, by members of the adoption community (HRSCFHS, 2005b). The following excerpt highlights the perceived disconnection between past and present.

There is a problem coming from the universities. There seems to be a mind-set that has got to be at least 30 or 40 years old that goes back to the bad old days of the stolen generation and back to when adoptions were things that were considered secrets and the hideous problems that young teenagers had to go through...There were mistakes made, but we have to move forward. It is not 1975; it is 2005...We have got to be progressive and move forward (HRSCFHS, 2005b, p. 4).

This view of a 'bad old days’ of domestic adoption that is completely disconnected from the good - progressive and forward moving - present of intercountry adoption is reflected in the final report of this inquiry. The final report deals briefly with submissions received from mothers 'forced to give up children against their will' between the 1950s and 1970s and moves swiftly to the purportedly reformed adoption of the contemporary period - sliding over the fact that intercountry adoption has remained unaltered by moves to openness and reforms in local adoption (Cuthbert, Spark, \& Murphy, 2010, p. 441; HRSFCHS, 2005a, p. 3) 


\section{Persistence of the past in intercountry adoption practices}

In contrast to the view that we can easily put the past behind us, this paper argues that practices that align with now discredited past domestic adoption practices in Australia are part of intercountry adoption's history and present conduct. In other words, it is not possible to quarantine intercountry adoption from past practices in domestic adoption. Framed by the social work values of social justice and human rights, we critically explore the implications of the 2012 Australian apologies for adoption practices by examining two main assumptions. These are that an elastic approach to ethical concerns is justifiable in intercountry adoption because of its differences from local adoption and that Australia’s past adoption practices bear no relevance to intercountry adoption as it is practised today. This critique focuses specifically on how the recognition of harms caused by past actions expressed within the current apologies has implications for intercountry adoption, the dominant form of non-relative adoption in contemporary Australia (AIHW, 2011). A critical perspective on past, present and future adoption practices explores adoption through the lens of social work values and ethics, and research-generated knowledge that includes historical perspectives (AASW, 2010; Cuthbert et al., 2010; Cuthbert \& Quartly, 2012). This focused analysis of prevalent assumptions both popular and professional on the subject of intercountry adoption reveals ethical and value concerns for social work that require rigorous debate and a focus on developing ways to address these tensions in practice. Future apologies to those adversely affected by intercountry adoption are forecast as practices (or toleration of practices) that have been discredited and apologized for in the domestic space persist. 


\section{Intercountry adoption as a practice in which ethical considerations may shift}

It is well documented that intercountry adoption is a complex phenomenon affected by power, multiple influences, opposing views and debates on the best interests

of children. Social workers are often caught between competing interests and politicking aimed at advancing specific agendas (Bartholet \& Smolin, 2012; Spark \& Cuthbert, 2009). Intercountry adoption is located on a continuum of legitimate permanency planning options, however there are no easy answers concerning the best interest of children and it is not our intention to engage in these debates in this paper. Rather, we underline where inclusion, human rights and social justice are impaired and how the disempowerment of those affected is maintained by adoption practices that do not equally protect the rights of all parents who give birth to children. And how the execution of intercountry adoption permits practices with respect to processes of relinquishment, rights to information and contact with birth families for children born overseas that are not tolerated for local, Australian children. This produces a double standard in adoption depending on the place of birth of the child.

\section{Masking the double standard in adoption: 'but intercountry adoption is different!'}

Multiple assumptions prevail in the production of a false dichotomy which seeks to segregate domestic and intercountry adoption, that is, the separation of the experiences of mothers, fathers and families in Australia from those of mothers, fathers and families overseas. Australian domestic adoption policy and practice have been transformed in the last three decades due to the activism of those affected by adoption and the work of social 


\section{Running Head: APOLOGIES FOR FORCED ADOPTION PRACTICES}

workers. Yet, practices acceptable in intercountry adoption remain markedly different from those accepted by Australian governments with respect to the adoption of Australian children. Certain standards of practice have been established as inappropriate for Australian children and their families of birth (as confirmed by apologies made by state and territory governments and the forthcoming Commonwealth apology), yet these same standards are not applied to children born overseas and their families (Cuthbert et al., 2010; Fronek, 2009a).

This difference is the 'slippery slope' when one considers this dichotomy in ethical terms rather than focusing singularly on the legal status of adoptions. Intercountry adoption is conceptualised as 'different' and therefore lesser standards are tolerated for children and for their families of origin. The experiences of birth families, mothers in particular, are identified as the 'elephant in the room' whenever intercountry adoption is discussed or communities are consulted (Smolin \& Smolin, 2012). Their invisibility is evident in the prevalence of discourses of 'orphanhood', 'rescue' and 'humanitarianism' in intercountry adoption debates. Despite the now dominant operation of intercountry adoption as a ‘service’ for infertile couples and individuals and its progressively regularized and now 'harmonised' practice, this form of adoption continues to be viewed and promoted as a response to children in need. The assumed self-evident good of being adopted into a relatively affluent overseas family is presented as justification for the disregarding of considerations that might otherwise apply and do apply in the case of domestic adoption, particularly in Australia.

As with Australian forced adoptions and similar adoptions in other jurisdictions (Fessler, 2006), coercive practices in intercountry adoption lie on a continuum from child 


\section{Running Head: APOLOGIES FOR FORCED ADOPTION PRACTICES}

trafficking to societal, professional or familial pressure to the absence of alternatives rather than adoption being driven by a desire to not raise one’s child. Child trafficking does occur in intercountry adoption. Australia is affected and vulnerabilities in the intercountry adoption system have been identified (Claire, 2012). Though exact numbers have not been released, the countries most recently identified by Claire (2012) as sources of trafficked children are India and Ethiopia. The Ethiopian program to Australia is currently closed and the Australian government is under considerable pressure from adoptive parent groups to reopen the program. The Indian program is on hold, that is, no new applications are being accepted, and the program is under review by federal government. Of course not all children are trafficked and many are legally available for adoption, but this does not mean that their mothers did not experience the same level of coercive practices reported by Australians mothers in past forced adoptions (Cheater, 2009; Cole, 2009). Where a child's adoption is driven by poverty, lack of support, societal disapproval, the stigmatization of children born outside of marriage and practices geared towards the facilitation of adoption, the reality of free choice in decisions must be examined.

Children are adopted internationally primarily due to poverty where basic income supports to help poor parents and families through times of crises do not exist (Fronek \& Cuthbert, 2012b; Gibbons \& Rotabi, 2012; Willing, Fronek, \& Cuthbert, 2012). Research identifies that children are often adopted from orphanages where they have been placed temporarily (Dickens, 2002; Zigler, 1975). Government policies, such as the One Child Policy in China, provide the structural conditions for the separation of children from their families (Johnson, 2012; 2005). There are reports from many countries that mothers and 


\section{Running Head: APOLOGIES FOR FORCED ADOPTION PRACTICES}

families do not understand the Western concept of adoption and often agree to separation from their children on the promise that their children will be educated with little comprehension of the permanent and legal nature of the separation (Bergquist, 2009). Qualified and disinterested interpreters are seldom used in adoption negotiations and assessments by qualified and impartial professionals are rare in some countries. While illegal in Australian jurisdictions, some overseas babies are identified for adoption while mothers are still pregnant and 'cooling off' periods, if they exist at all, fall far short of the standards accepted in Australia. There are also reports of mothers signing consents when drugged just as reported in earlier Australian practices (Gair, 2009). Different problems emerge in in different countries, but research confirms the lack of choice is in itself coercive (Hogbacka, 2008; 2012).

It is assumed that exceptions to acceptable adoption practice in intercountry adoption are necessary to save the lives of individual children or at least to deliver them from institutionalization. Again, a false dichotomy - intercountry adoption or a life of poverty or institutionalisation - is deployed which effectively prevents parties actively working on a range of alternatives to both adoption and institutionalisation such as community development and family preservation strategies, temporary non-institutional care arrangements and the utilisation of traditional means of caring for children. From the Australian experience, we know that the provision of adequate child support for single mothers in 1973 was sufficient to empower many unmarried women to resist the pressure to adopt and raise their children. It was the advent of income support in the context of other societal shifts that changed the course of adoption in Australia, a safety-net markedly absent from intercountry adoption sending countries. Some intercountry 


\section{Running Head: APOLOGIES FOR FORCED ADOPTION PRACTICES}

adoption scholars have proposed on multiple occasions that if the money invested into intercountry adoption was invested into community development that strengthened families and communities, different outcomes would be achieved and the impact of inequality and poverty would be alleviated (Smolin, 2007). This approach necessitates confirmation that these children are not "orphans" and that families, in most instances, do exist, and a rejection of discourse that promotes intercountry adoption as a solution to poverty. Confronting the powerful vested interests in the adoption industry, and in parent organisations that use the media to advance their interests in accessing greater numbers of children with fewer impediments (usually framed as red tape or bureaucracy) for adoption is also necessary.

A value-based and ethical approach to adoption requires us to commit to all parents and families receiving the same treatment regardless of where they are positioned in any decision making process. Decisions to adopt should be informed and free of coercive practices whether at structural or interpersonal levels and children born overseas and adopted into Australia should be accorded the same rights of access to information as Australian-born adoptees.

\section{Reconciling past and present}

As social workers, it is important to understand the relationships between the past and present, not only in terms of social injustice and breaches of human rights and dignity, but also in terms of our own practice. In the 1960s to the 1980s, not all Australian professionals identified as social workers were social workers (Gair, 2009). Similarly, in intercountry adoption there are assumptions that overseas adoption workers 


\section{Running Head: APOLOGIES FOR FORCED ADOPTION PRACTICES}

are social workers with little attempt to clarify qualifications by governments receiving children. The reality is not all workers in intercountry adoption are social workers nor are they necessarily indigenous to the countries in which they practice. They and their perspectives on adoption practice are often Western and imported into the local scene and, in many cases, serve the interests of prospective adoptive parents in the West. In many countries, social work is a new profession. Establishing culturally appropriate and adequately educated social work professionals in dynamic, geopolitical climates remains a challenge for the profession as a whole, especially supporting the global profession's efforts to practice ethically and competently in family work and adoption (Rotabi, Pennell, Roby, \& Bunkers, 2012). The appropriate use of the professional title, social worker, is important as it implies certain levels of competency, ethical behaviour and guiding philosophies associated with accredited standards required by associations of social work, registration boards and legislative requirements in some countries. There should be accuracy when describing social workers and other workers in the adoption field both overseas and in Australia.

Drawing on Gair's (2009) work, it is useful to examine the past experiences of those professionals who were social workers and how their practice was influenced by the dominant discourses of society at that time and compare these experiences to intercountry adoption. Gair (2009) reports that tensions did exist between perspectives of social workers and other public servants, religious workers and professionals in hospital cultures. Dominant perspectives included decisive and limited notions of family, deserving and undeserving parenting and salvationist beliefs. Adoption was identified as saving children (and their mothers) from a shameful life and re-authoring their lives to 


\section{Running Head: APOLOGIES FOR FORCED ADOPTION PRACTICES}

one in families deemed acceptable by society. Alongside these pressures, adoption was 'happy' work for social workers who in other fields dealt constantly with human problems. Adoptive parents were happy, adopted children were granted better lives while parents and birth families were rendered invisible in legal and closed process. It is understandable that 'feel good' work was attractive to a fledgling profession, but, as Gair (2009) identified, a paradigm shift occurred with the professionalisation of social work in Australia related to university education and the critical perspectives it enables. As a profession, in both adoption practice and academic comment on it, it is crucial that social workers continue to seek deeper knowledge of adoption and the experiences of those adversely affected. It is equally important that critical reflection and ethical practice as outlined by the Australian Association of Social Workers (AASW) Codes of Ethics and other social work codes is integral to maintaining the highest ethical and professional standards as they apply to social work adoption practices in Australia and overseas.

Today, Australian social workers and other human services practitioners are subjected to enormous pressure from politicians and lobbying groups promoting the practice of intercountry adoption to reduce waiting times, increase numbers and find new source countries of children (Fronek, 2009a,b; Fronek \& Tilse, 2010). Increasingly, social workers are marginalised in these political and legal negotiations which often gain media attention and scrutiny. It could be argued this marginalisation is consequent to the deprofessionalisation of social work beginning in the 1990s and the expanded role of the federal government following the 2005 inquiry into adoption (Chenoweth \& McAuliffe, 2012; HRSCFHS, 2005a). Whereas, supporting couples to form families is 'happy work' (Gair, 2009) and the pragmatic focus of social workers (Rotabi \& Bunkers, 2011) is on 


\section{Running Head: APOLOGIES FOR FORCED ADOPTION PRACTICES}

ensuring that processes in Australia are ethical, competent and professional. The important question to be debated is how social workers can be supported to move past purely pragmatic positions to influence policy and practice at structural levels where families are disadvantaged and communities depleted of their children because lesser standards are accepted for people elsewhere to meet the interests of lobbyists and claims makers in Australia (Best, 1995).

Government sanctioned intercountry adoption is not yet forty years old in Australia and lags behind receiving countries in North America and Europe by twenty years. Dominant discourses on the adoption of overseas children essentially remain unchanged since the 1950s when proponents such as author, Pearl S. Buck, wrote dramatically about Asian orphans and western-style orphanages, still the dominant form of pre-adoption care, as the answer to post-war chaos (Fronek \& Cuthbert, 2012b). In the same period, the social work profession and its body of knowledge has not stayed still. Knowledge has extended to include Indigenous and environmental social work while the emphasis on critical reflection and a commitment to social justice and human rights has strengthened. Likewise knowledge about intercountry adoption has grown exponentially and we can no longer claim ignorance about the effect of poor practices on people, their children and communities. The Australian apologies reinforce this perspective.

Assumptions exist and are perpetuated that, as a nation, we cannot and should not influence adoption practices elsewhere. At an international level, we do support countries to become Hague compliant (Convention on Protection of Children and Co-operation in Respect of Intercountry Adoption) in order to facilitate adoptions, yet we are reluctant to influence other countries in terms of child welfare and relinquishment practices. This 
could be, in part, resistance to persistent lobbying to exert pressure on other countries to open their doors to adoption or increase the numbers of children they make available. However, it has been noted as far back in the 1970s that Australia has been in competition with other countries for the adoption of a limited number of children and has indeed sought new source countries as a response to lobbying pressure (Fronek, 2009a). Generally, intercountry adoptions thrive when political perspectives are neoliberal and free market approaches are favoured (Dickens, 2009). At present Australia has no private adoptions, but there is considerable pressure to introduce them. Australia has strong economic ties in trade with a number of countries from whom we receive or have received children and has exercised influence to commence programs even with countries that are not signatories to the Hague Convention on Protection of Children and Cooperation in Respect of Intercountry Adoption 1993, such as the opening of the China program in 1999 (China has since become party to the Hague Convention). Yet, Australia remains reluctant to influence the development of standards relating to adoption, preferring to ensure that programs are legal while current limitations to human rights and social justice commitments are accepted.

Coercive practices may also be apparent in some types of domestic adoptions in receiving countries of children. For example, some domestic adoptions are court ordered for children in care in the United Kingdom and United States (Kirton 2012). There are indications from the current Queensland Child Protection Commission of Inquiry (QCPI,2012) and the New South Wales Government’s Child Protection Legislative Reform Discussion Paper, and the 2005 Inquiry into Overseas Adoption (HRSCFHS, 2005a) that while apologizing for past forced removals, some Australian states may 


\section{Running Head: APOLOGIES FOR FORCED ADOPTION PRACTICES}

permit adoptions without parental consent for children in State care. In 2005, the Chair of the Inquiry into Overseas Adoption, Bronwyn Bishop, made her views explicit in the final report, that is, that the adoption of children from foster care would provide a solution for those people wanting to adopt children.

\section{Conclusions}

Intercountry adoption is located on a continuum of legitimate permanency planning options. Its practice has become the preferred option for the care of children unable to be cared for by their families in many sending countries and meets the needs of powerful stakeholders with vested interests in adoption in receiving countries. The subsidiarity principle of The Hague Convention that states local options are preferred over intercountry adoption, purported as a last resort, is glossed over in practice. Little diplomatic influence or other support from receiving countries for capacity-building efforts directed at ensuring culturally-appropriate alternatives to adoption are employed; nor are standards, such as those which apply in receiving counties pertaining to relinquishment, required. Where there is a sole focus on servicing Western-style adoptions in sending countries, both domestic and international, activities that build family and community capacities are neglected and, in that process, attention to human rights (including the rights of children) and social justice as it concerns the most disadvantaged in overseas communities is minimized. The result is a complicity in obscuring the range of human rights issues which cluster around intercountry adoption in favour of the right to a wholly Western version of family for these children - at the cost of contact with their identity, culture, communities, immediate and extended families. In 


\section{Running Head: APOLOGIES FOR FORCED ADOPTION PRACTICES}

contrast with this prevalent practice, governments, communities and stakeholders are obligated to explore alternatives to adoption and expatriation (ACPF, 2012a,b), address inequality and work together to ensure the same standards apply in all adoptions.

The sum of research and informed comment on intercountry adoption as a global practice leads to only one conclusion: while for individual children, the outcomes from intercountry adoption may be positive, as a practice it is enabled by gross disparities in wealth and power. This disparity leads, as it did in previous decades in Australia, to the placement of children for adoption in circumstances marked by necessity, deception, poverty, lack of freedom or coercion. Forced adoption practices are not a thing of the past. They persist in intercountry adoption.

Policy makers and public servants are increasingly aware of the injustices explicit in intercountry adoption practices due to the growing body of research conducted in sending countries of children but are influenced by the complexities of bureaucracies, politics, international relations and the dominance of discourse bestowing a 'veneer of philanthropy’ on its practice (Harrop, 2012). Fejo-King (2011) highlights how the apology culture in contemporary Australia demonstrates that officials will be held to account for their actions at some time in the future. Social workers, parents, policy makers, legislators and all concerned with the intercountry adoption of over 10,000 children to Australia since the late 1960s (Rosenwald, 2009) need to prepare to make a full account of the actions taken in this regard. As a nation, we should now prepare for a future apology for our continued complicity in practices in relation to children born overseas that we have not considered acceptable for Australian-born children and their families for some time and for which Australian state and territory governments and the 


\section{Running Head: APOLOGIES FOR FORCED ADOPTION PRACTICES}

Commonwealth are now apologising. An apology for forced practices in intercountry adoption, despite being strongly resisted by parent lobbying groups as a universal criticism, has as much legitimacy as apologies for other practices. There is a growing movement of those persons affected by forced intercountry adoption practices that is not limited by national borders or 'triad' membership (parent, adoptive parent and people who were adopted) looking to Australia to set the example and precedent for further apologies in other countries. This paper focused on an apology which would be the first step in acknowledging and subsequently influencing certain practices that are currently tolerated in order to facilitate adoptions. The Australian climate is politically volatile at this point in time with intense lobbying and celebrity representation that promotes deregulation and outcomes measured by the numbers and expedition of adoptions achieved. Australia is at a crucial juncture where either the status quo will be maintained in intercountry adoptions or new models that favour the private market and reflect the neoliberal agenda on child welfare or the devolution of state responsibilities will be introduced. An apology will bring additional considerations to be debated and require current policies and practices to be examined through a different lens. 


\section{Running Head: APOLOGIES FOR FORCED ADOPTION PRACTICES}

\section{References}

Australian Association of Social Workers (AASW). (2010). Code of Ethics. Retrieved $3^{\text {rd }}$ September, 2012, from http://www.aasw.asn.au/document/item/740/.

African Child Policy Forum (ACPF). (2012a). Intercountry Adoption: An African

Perspective. Retrieved August 23, 2012, from http://www.africanchildforum.org/site/index.php/inertnational-policyconference.html.

African Child Policy Forum. (2012b). Africa: The New Frontier for Intercountry Adoption. Retrieved August 23, 2012, from http://www.africanchildforum.org/site/index.php/inertnational-policyconference.html.

Australian Institute of Health and Welfare (AIHW). (2011). Adoptions Australia 201011. Canberra: Australian Government.

Bartholet, E., \& Smolin, D. M. (2012). The debate. In J. L. Gibbons \& K. S. Rotabi (Eds.), Intercountry adoption: Policies, practices and outcomes (pp. 233-251). UK: Ashgate.

Bergquist, K. J. S. (2009). Operation Babylift or Babyabduction?: Implications of the Hague Convention on the humanitarian evacuation and 'rescue' of children. International Social Work, 52(5), 621-633. doi: 10.1177/0020872809337677.

Best, J. (1995). Images of issues: Typifying contemporary social problems (2nd ed.). New York: Aldine De Gruyter.

Cheater, C. (2009). 'My brown skin baby they take him away': A reassessment of the role of adoption in the forced removal of Aboriginal children from their families. In C. 
Running Head: APOLOGIES FOR FORCED ADOPTION PRACTICES

Spark \& D. Cuthbert (Eds.), Other people's children: Adoption in Australia (pp. 176-194). Melbourne, Victoria: Australia Scholarly Publishing.

Chenoweth, L., \& McAuliffe, D. (2012). The road to social work and human services practice (3rd ed.). South Melbourne, Victoria: Cengage Learning.

Claire, S. (2012). Child Trafficking and Australia's Intercountry Adoption System. Retrieved $28^{\text {th }}$ August, 2012, from http://www.law.uq.edu.au/documents/humantraffic/child-trafficking/Childtrafficking-and-Australias-intercountry-adoption-System.pdf.

Cole, C. (2009). The hidden tragedy of the white stolen generation and its consequences: Perspectives on adoption in Australia from a mother of the white stolen generation. In C. Spark \& D. Cuthbert (Eds.), Other people's children: Adoption in Australia (pp. 110-126). Melbourne, Victoria: Australian Scholarly Publishing.

Cuthbert, D., Spark, C., \& Murphy, K. (2010). "That was then, but this is now": Historical perspectives on intercountry adoption and domestic child adoption in Australian public policy. Journal of Historical Sociology, 23(3), 427-452. doi:10.1111/j.1467-6443.2010.01376.x

Cuthbert, D., \& Quartly, M. (2012). "Forced adoption" in the Australian story of national regret and apology. Australian Journal of Politics and History, 58(1), 82-96.

Dickens, J. (2002). The paradox of inter-country adoption: Analysing Romania's experience as a sending country. International Journal of Social Welfare, 11(1), 76-83.

Dickens, J. (2009). Social policy approaches to intercountry adoption. International Social Work, 52(5), 595-607. doi: 10.1177/0020872809337678. 


\section{Running Head: APOLOGIES FOR FORCED ADOPTION PRACTICES}

Edwards, J. A. (2010). Apologizing for the past for a better future: Collective apologies in the United States, Australia, and Canada. Southern Communication Journal, 75(1), 57-75. doi:10.1080/10417940902802605

Fejo-King, C. (2011). The national apology to the stolen generations: The ripple effect. Australian Social Work, 64(1), 130-143. doi:10.1080/0312407x.2010.542564

Fessler, A. (2006). The girls who went away: The hidden history of women who surrendered children for adoption in the decades before Roe V. Wade. New York: Penguin Press.

Fronek, P. (2009a). Understanding the emergence, diffusion and continuance of intercountry adoption from South Korea to Queensland. Unpublished PhD thesis, University of Queensland, Brisbane, Australia.

Fronek, P. (2009b). Intercountry adoption in Australia: A natural evolution or purposeful actions. In C. Sparkes \& D. Cuthbert (Eds.), Other people's children: Adoption in Australia (pp. 37-54). Melbourne, Victoria: Australian Scholarly Publishing Pty Ltd.

Fronek, P. (Interviewer). (2012). Contemporary issues for international adoptees: In conversation with Tobias Hubinette [Episode 20]. Podsocs. Podcast retrieved August $23^{\text {rd }} 2012$ from www.podsocs.com

Fronek, P., \& Cuthbert, D. (2012a, June 25). An apology to forced adoption birth mothers: it’s about time. Message posted to https://theconversation.edu.au/anapology-to-forced-adoption-birth-mothers-its-about-time-7875. 


\section{Running Head: APOLOGIES FOR FORCED ADOPTION PRACTICES}

Fronek, P., \& Cuthbert, D. (2012b). The future of intercountry adoption: A paradigm shift for this century. International Journal of Social Welfare, 21(2), 215-224. doi: 10.1111/j.1468-2397.2011.00799.x

Fronek, P., \& Tilse, C. (2010). Controversy and its implications for the practice of contemporary social work in intercountry adoptions: A Korean Australian case study. Australian Social Work, 63(4), 445-459.

doi:10.1080/0312407X.2010.512957

Gair, S. (2009). Hearing the voices of social workers in past adoption practice with mothers and their babies for adoption: What can we learn? In C. Spark \& D. Cuthbert (Eds.), Other people's children: Adoption in Australia (pp. 75-94). Melbourne, Victoria: Australian scholarly Publishing.

Gibbons, J., \& Rotabi, K. S. (Eds.). (2012). Intercountry adoption: Policies, practices and outcomes. UK \& USA: Ashgate.

Harrop, E. W. (2012, August 6). Adopting from Africa, Saving the children? Retrieved August 23, 2012, from http://thinkafricapress.com/legal/adoption-trade-sets-shopafrica.

Hogbacka, R. (2008). Transnational adoption and the exclusiveness and inclusiveness of families. Retrieved $8^{\text {th }}$ August, 2011, from http://www.kumsn.org/main/?document_srl=904\&mid=kumsn_resources_unwed.

Hogbacka, R. (2012). Maternal thinking in the context of stratified reproduction. Perspectives of birth mothers in South Africa. In J. L. Gibbons \& K. S. Rotabi (Eds.), Intercountry adoption: Policies, practices and outcomes (pp. 143-159). UK: Ashgate. 


\section{Running Head: APOLOGIES FOR FORCED ADOPTION PRACTICES}

House of Representatives Standing Committee on Family \& Human Services

(HRSCFHS). (2005a). Overseas adoption in Australia. The report on the inquiry into adoption of children from overseas. Canberra, Australian Capital Territory:

The Parliament of the Commonwealth of Australia.

House of Representatives Standing Committee on Family \& Human Services

(HRSCFHS). (2005b, September 23). Adoption of children from overseas. Public hearing Retrieved $3^{\text {rd }}$ September, 2012, from http://parlinfo.aph.gov.au/parlInfo/search/display/display.w3p;query=Id:committe es\%2Fcommrep\%2F8714\%2F0001

Johnson, K. (2005). Chaobao: The plight of Chinese adoptive parents in the era of onechild policy. In T. A. Volkman (Ed.), Cultures of transnational adoption (pp. 117141). Durham and London: Duke University Press.

Johnson, K. (2012). Challenging the discourse of intercountry adoption: Perspectives of Rural China. In J. L. Gibbons \& K. S. Rotabi (Eds.), Intercountry adoption: Policies, practices and outcomes (pp. 103-117). UK: Ashgate.

Kirton, D. (2012). ‘Kinship by design’ in England: reconfiguring adoption from Blair to the coalition. Child \& Family Social Work, doi: 10.1111/cfs.12027.

QCPCI. (2012). Queensland Child Protection Commission of Inquiry.Brisbane.

Rosenwald. T. - we need to cite her demographic essay in other people’s children

Rotabi, K. S., \& Bunkers, K. M. (2011). In an era of reform: A review of social work literature on intercountry adoption. SAGE Open, 1(3), 1-16.

doi:10.1177/2158244011428160 


\section{Running Head: APOLOGIES FOR FORCED ADOPTION PRACTICES}

Rotabi, K. S., Pennell, J., Roby, J. L., \& Bunkers, K. M. (2012). Family group conferencing as a culturally adaptable intervention: Reforming intercountry adoption in Guatemala. International Social Work, 55(3), 402-416. doi: $10.1177 / 0020872812437229$

Short, D. (2012). When sorry isn't good enough: Official remembrance and reconciliation in Australia. Memory Studies, 5(3), 293-304. doi:10.1177/1750698012443886

Smolin, D. M. (2007). Intercountry adoption and poverty: A human rights analysis. Capital University Law Review, 36(2), 413-453.

Smolin, D. M., \& Smolin, D. L. (2012, April 18). The aftermath of abusive adoption practices in the lives of adoption triad members: Responding to adoption triad members victimized by abusive adoption practices. Retrieved August 14, 2012, from http://works.bepress.com/david_smolin/12/

Spark, C., \& Cuthbert, D. (2009). Other people's children: Adoption in Australia. Melbourne, Victoria: Australian Scholarly Publishing.

Willing, I., Fronek, P., \& Cuthbert, D. (2012). Review of sociological literature on intercountry adoption. Social Policy and Society, 11(3), 465-479. doi:10.1017/S1474746412000140

Zigler, E. (1975). The Vietnamese children's airlift: Too little and too late. Retrieved 13 March, 2010, from http://eric.ed.gov/ERICWebPortal/custom/portlets/recordDetails/detailmini.jsp?_n fpb=true\&_\&ERICExtSearch_SearchValue_0=ED119827\&ERICExtSearch_Sear chType_0=no\&accno=ED119827. 